EPiC Series in Built Environment
Volume 1, 2020, Pages 283-291
$\begin{gathered}\text { Associated Schools of Construction Proceed- } \\ \text { ings of the 56th Annual International Conference }\end{gathered}$

\title{
Exploring the Synergy Between Lean Construction and Flash Track Implementation
}

\author{
Pardis Pishdad-Bozorgi, Ph.D. and Sooraj Kumar, Graduate Student. \\ Georgia Institute of Technology \\ Atlanta, Georgia
}

Speed-driven projects require extensive planning and coordination for their successful execution within the specified time and cost. With an increasing demand for flash track execution, more efficient ways for project implementation is needed. Lean construction is having a profound impact on the construction industry, which is perceived to be suffering from cost and schedule overruns. This review paper investigates the use of various lean tools and principles in flash track projects and if there is any synergy between lean and flash track projects to improve productivity and schedule performance.

Through rationalizations and with the help of case studies and theoretical evidence found in literature, eleven lean tools and eight lean principles have been analyzed for their synergy with flash track construction. The results indicate that all except one lean tool (Just in Time) and one lean principle (reduce inventory) facilitate successful implementation of flash track project.

Key words: Flash track, fast track, Lean construction, Lean tools, Lean principles,

\section{Introduction}

The Construction industry today is plagued by many challenges such as late project completions and decreasing productivity. The US Bureau of Labor Statistics indicates that construction productivity has declined by $0.5 \%$ each year from 1964 to 2003 (Teicholz, 2013). Reasons for this poor performance has been attributed to industry fragmentation, excessive litigation, diminished skill workforce, limited collaboration and lack of trust (Langford \& Murray, 2003). With an increasing demand for faster project delivery by owners, for reasons such as emergency rebuilds and competitive market forces, challenges of planning and coordination of construction work need to be addressed for their timely completion.

Emerging trends such as Building Information Modeling (BIM), Lean Construction, Integrated Project Delivery (IPD) have been used in recent construction projects to address the issues of fragmentation, delays, waste and inefficiencies through improved project integration. Case studies undertaken such as the study by (Bertelsen, Christoffersen, Jensen, \& Sander, 2001) have shown that the implementation of lean principles in Denmark have led to increased productivity by $20 \%$, minimized project duration by $10 \%$, expanded efficiency by $20 \%$ and enhanced profitability by $20 \%$ 40\%. Similarly, Austin (2016) presented Thyssen Krupp's New Steel Processing Facility case study, which had implemented Lean construction tools such as Last Planner System®, Pull Planning, Daily 
Huddles to accelerate learning and collaboration and resulted in a $19 \%$ earlier project completion than the traditional method. Due to these proven results, this review paper aims to investigate the use of the various Lean tools and principles in flash track projects and find if and how there is synergy between the lean and flash track implementation.

\section{Flash-Track Implementation}

Flash track is defined as a "time driven projects which by necessity requires a heightened degree of concurrency between engineering, procurement and construction" and differs from fast-tracking on the basis of time. Thus, it denotes faster fast tracking, which requires intensified planning and coordination (Pishdad-Bozorgi \& de la Garza \& Austin, 2016). There are different types of projects which require flash tracking, specifically - emergency rebuilds, regulatory compliance, first to market competition and funding availability (Austin, 2016). The risks associated with flash tracking includes volatility risks in addition to typical risks of cost overruns, design errors, change orders, and reworks (Moazzami, Dehghan, \& Ruwanpura, 2011). Risks of rework, change orders are usually high in a traditional management system where the task plans are rushed. They often lead to a loss of labor productivity and project delay (Fazio, Moselhi, Théberge, \& Revay, 1988). However, this paper conjecture is that these flash track risks can be mitigated through Lean Construction with the help of careful planning. Previous studies conducted by have identified 47 best practices for flash tracking (Pishdad-Bozorgi \& de la Garza \& Austin, 2016). Lean tools and principles can facilitate implementation of a few flash track practices, such as the use of multi-skilled personnel, staffing with cooperative and collaborative personnel, minimizing handoffs, identifying and procuring long lead items, reducing risks through collective efforts, engaging contractors early can be implemented with the help of in the flash track projects.

\section{Lean Construction}

The Construction Industry Institute has defined lean construction as "the continuous process of eliminating waste, meeting or exceeding all owner requirements, focusing on the entire value stream, and pursuing perfection in the execution of a constructed project". "Lean is a way to design production systems to minimize waste of materials, time and effort in order to generate the maximum possible amount of value." (Koskela et al. 2002). The ideas of the new production philosophy first originated in Japan in the 1950's through the Toyota Production System for eliminating inventories and other waste through small lot production and reduced set up times (Koskela 1992). The term "lean" was first used in 1988 by Krafcik and applied to construction in 1993. According to one study on the time spent by builders when building gypsum block partitions by Sacks et al. (2008), only 31.9\% of the time was spent on value adding activities (building) while the rest was non-value adding activities such as waiting and rework, design changes etc. Lean construction is a conceptual approach to project and construction management with a focus on reduction of waste; transportation, overproduction, motion, waiting, overprocessing, defects, inventory, and thus it improves the project performance. To reduce these wastes, lean construction applies the concept of pull system over the traditional push system.

Pull planning is a lean technique where real-time feedback from construction and off-site fabrication activities are provided so that process steps are realistic. Pull planning is used to reduce the uncertainties as well as improve the work-plan reliability by "pulling" the required information and resources through the supply chain. In this approach, work starts only when the work is ready for the workers.

The new production philosophy (Koskela 1992) aims to improve the value stream by identifying and removing superfluous activities and interfaces between teams, increasing the stability of the flow of 
work and information, as well as reducing the quantities of work-in-progress (WIP) (Sacks, Korb \& Barak 2017). The new production philosophy views construction as composed of flow processes such as the flow of materials, information and construction teams. Little's law is an applicable mathematical model which explains the flow in production (Little \& Graves, 2008a). It states that throughput is measured as number of units of a product produced per unit of time. WIP is the quantity of incomplete product units in the production system at any given point of time. Cycle Time is the time required to produce a single product. A lean production system operates at or very near to the boundary of WIP $=\mathrm{W}_{0}$ where $\mathrm{W}_{0}$ is the amount of WIP which has the minimum cycle time (see Figure 1). The idea of "Lean" is that the quantity of unfinished products such as apartments, and the wastes associated with them is equal to some practical minimum. The batch size in ideal conditions in a lean system is reduced to one. A Lean production system also has stable and predictable production rates (Sacks 2008).
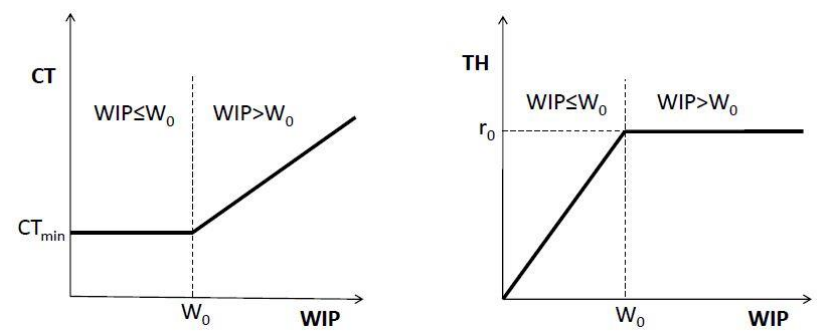

Figure 1. Little's Law relationship between Throughput (TH), Work in Progress (WIP) and Cycle Time(CT) (Little \& Graves, 2008b).

Eight lean principles have been analyzed for their application in flash track projects. These selected principles are reducing variability, cycle time, batch size, inventory, using multi-skilled teams and pull systems as well as instituting continuous improvement. These principles are intended to improve the flow of work by increasing reliability of the upstream flow and increase the productivity of the workers.

Variability - Variability can be in the form of workstation setup times and production rates, change orders, people's level of skill and effort, levels of demand. Increasing variability can reduce the throughput of the production line, thus increasing the cycle time and work in progress. Variability can be reduced by allowing small amount of inventory so that the work continues even if there is a disruption. (Hopp and Spearman)

Batch Size - Batch size is the total number of locations that are assigned to a trade crew to work in, at any given point of time (Sacks 2007). Reducing the batch size refers to reducing the number of locations assigned as a batch. In an ideal situation, the batch size should be one according to lean thinking.

Multi skilled teams - Staffing with multi skilled personnel in flash track projects was recognized as one of the best practices (Austin et al. 2016). It can be used to improve the work process where each team performs larger packages of continuous work. Due to fewer interruptions between work packages, the work-in-progress (WIP) and cycle times are also reduced.

Continuous Flow- It is a type of production line through which work is advanced from one production station to another on a first-in-first-out basis to achieve maximum throughput of that part of the system while minimizing work-in-progress (Sacks, 2016a).

Pull System - Work commences only by a demand from a downstream work station (or customer) in a pull system (Sacks, Koskela, Dave, \& Owen, 2010).

Institute continuous improvement - The concept of continuous improvement was developed by Toyota Motor Company in 2001. Continuous improvement can be developed through "Daily Kaizen" where the workforce is not only challenged to do their work, but also be responsible for improving them. 
The definition of a principles is "a fundamental truth or proposition that serves as the foundation for a system of belief or behavior or for a chain of reasoning." Similarly, lean principles serves as a foundation on which lean tools have been developed and used in the lean project delivery system. It is intended to improve the delivery system by minimizing wastes, improving flow and productivity in a construction site by guiding people to think in a lean way. This paper considers eleven lean tools: Last Planner System ${ }^{\circledR}$, Concurrent Engineering, Just-in-time, 5S, Daily Huddle Meetings, A3, Kanban, Continuous Flow, Poka-Yoke, Work Structuring, Work Standardization, and Value Stream Mapping. These tools have been analyzed to determine if they have synergy with flash tracking. Published case studies and existing literature have been studied and cited as supporting evidence for the use of these lean tools in flash track projects.

Last Planner System ${ }^{\circledR}$ - The Last Planner System ${ }^{\circledR}$ (LPS) has been successfully implemented to stabilize work flow by making plans predictable and reliable, by involving builders in the planning process and getting their input to identify and remove constraints (Ballard, 2000). It entails planning at four levels (master planning, phase planning, look-ahead planning \& weekly work planning) and involves pull scheduling.

Concurrent Engineering-Concurrent Engineering is the systematic approach to the integrated design, construction, maintenance and operations. It is a production management philosophy which is used to achieve time-saving goals through overlapping the traditional activities (Bogus, Molenaar, \& Diekmann, 2005).

Just-in-time (JIT)- It is a technique developed by Taichi Ohno to reduce inventory and is employed to increase efficiency and decrease waste by receiving materials or equipment only as they are needed in the construction process. (Low Sui Pheng \& Choong Joo Chuan, 2001).

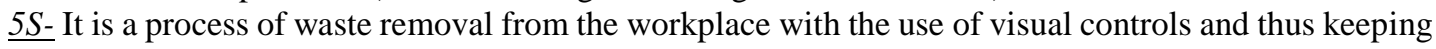
the work environment organized (Salem, Solomon, Genaidy, \& Minkarah, 2006a).

Daily Huddle Meeting-It is a technique which involves crew workers in the planning of everyday tasks where the team members give status updates about previous shift's accomplishment and failures, as well as current shift's plan of work for that day (Salem, Solomon, Genaidy, \& Luegring, 2005b).

$\underline{A} 3$-It is a tool used to assist the user to execute the Plan-Do-Check-Act process and solve problems by communication on a $11 \times 17$ piece of paper.

Kanban (Pull Signal)- This is a Japanese word which means 'card' or 'sign' and is a lean approach to pull materials and parts throughout the value stream on a just-in-time basis. It was developed by Taiichi Ohno to improve the manufacturing efficiency. (Sugimori 1977, Toyota Production System 1973).

Poka-Yoke- It is a Japanese word which means "mistake proofing". It uses visual or other signals to detect and prevent errors in processes with the aim of achieving zero defects (Tommelein, 2008).

Work Structuring - It is a fundamental form of planning which determines what work must be done, who would be best suited to execute it and when they should be doing it (Ghosh \& Robson, 2015).

Work Standardization-It is the extensive use of successful practices or procedures in a regular, repetitive manner (Alistair G.F. Gibb \& Frank Isack, 2001).

Value Stream Mapping- It is a technique for visually analyzing, documenting, and improving the flow of a process in a way that highlights improvement opportunities.

\section{Methodology}

The primary purpose of this research paper is to examine the potential synergy between lean construction and flash-tracking by exploring the rationale and gathering practical evidence from the existing publication, which demonstrates Lean tools and principles are found to be effective in improving schedule performance and productivity. These principles and tools were chosen based on the lean project delivery system. The research methodology involved three phases. Phase 1 focused on the literature review on Lean construction as well as flash tracking. Phase 2 entailed the data 
collection on various lean tools and principles implemented in construction projects. To find out if these lean tools have been effective in decreasing the duration of the projects, several key words were used such as "rapid", "fast", "lean" in the literature search. Phase 3 entailed the data analysis of the relevant lean tools and principles in flash tracking. This was implemented in two steps:

1. Formation of the rationale that presents the logical synergy between each lean tool and principle and flash tracking.

2. Identification of evidence from the publications.

\section{Result}

The analysis of eight lean principles and the eleven lean tools for their synergy with flash tracking is provided below.

\section{Synergy between Lean Principles and Flash Track Projects}

Reduce Variability

Rationale - Reduction of variability in the execution of tasks leads to a more reliable and predictable workflow and results in improved schedule performance.

Supporting Evidence - Koskela, (1992) states that variability in the flow of work increases the cycle time and reduces the throughput of the system by increasing the amount of waste in a process.

\section{Reduce cycle times}

Rationale - Reducing cycle times by optimizing the work-in-progress (WIP) results in increased throughput and improved productivity.

Supporting Evidence - Sacks \& Goldin (2007) concluded that the reduction of WIP by involving multiskilled teams, reducing cycle time, reducing batch size and using pull flow lead to an improved project performance.

$\underline{\text { Reduce batch size }}$

Rationale - Reducing batch sizes leads to improved cycle times and lowers the amount of work in progress inventory. This leads to improved workflow.

Supporting Evidence - Sacks \& Goldin (2007) states that reduction of batch size leads to a reduction in the duration to complete due to less amount of work-in-progress (WIP).

Reduce inventory

Rationale - Reducing inventory results in the reduction of buffer stock. However, fast track projects call for increased buffer stocks. In this sense, this particular lean principle has negative effects on flash track projects.

Supporting Evidence - Austin et al. (2016) states that flash tracking needs increased capacity of resources and buffer stocks.

Use multi-skilled teams

Rationale - Using multi-skilled teams leads to reduced setup and changeover times. This leads to increased productivity and eliminates wait time.

Supporting Evidence - According to Austin et al. (2016), one of the best practices for flash tracking includes using multi-skilled personnel. Sacks \& Goldin (2007) concludes that involving multi-skilled teams leads to longer periods of continuous work and fewer interruptions between work packages. This would also contribute to reducing the cycle time and work in progress (WIP) level. 
Continuous Flow

Rationale - Continuous flow eliminates interruptions in a workflow and leads to building momentum which would result in increased productivity and faster completion of tasks.

Supporting Evidence- Sacks (2016) states that continuous flow of processes results in no waiting time between operations.

Use pull systems

Rationale - "Pull" techniques are well suited for fast-track projects that require assembly of unique parts and that are plagued by uncertainties. Such projects are difficult to schedule accurately and in detail in advance. As uncertainties manifest themselves during project execution, the pre-construction schedule will have to be adjusted in a flexible manner for field work to progress efficiently and for work-in progress inventories to remain small. This would lead to stable and a reliable work flow and also mitigate delays.

Supporting Evidence - Tommelein, (1998) uses discreet event simulation to show that "pull" techniques leads to improved performance of a construction process.

\section{Institute continuous improvement}

Rationale - Continuous improvement can be implemented to make the process more efficient, reduce variability, and thus, improve the productivity and schedule performance.

Supporting Evidence - Austin et al. (2016) presented two case studies, Thyssen Krupp's New Steel Processing Facility and Maine General Medical Center, which employed continuous improvement techniques through the use of Lean construction. This lean principle lead to a more efficient process which resulted in an improved schedule performance.

\section{Synergy between Lean Tools and Flash Track Projects}

\section{$\underline{\text { Last Planner System }{ }^{\circledR}}$}

Rationale-Increase in collaboration between stakeholders results in improved schedule performance. Early involvement of key builders in the planning phase leads to a more reliable schedule with buyins from the builders.

Supporting Evidence - Case studies conducted by Austin (2016) such as Maine General Medical Center and ThyssenKrupp's New Steel Processing Facilities indicate the use of Last Planner System ${ }^{\circledR}$ in their projects improved the schedule performance.

\section{Concurrent Engineering}

Rationale - Through overlapping the sequential activities, the project delivery time can be reduced and the project can be flash-tracked.

Supporting Evidence - Bogus et al. (2005) concludes that the overlapping of sequential activities, by removing or reducing information dependencies among sequential tasks leads to significant time savings.

$\underline{\text { Just-in-time (JIT) }}$

Rationale - JIT calls for zero inventory and buffer stocks. However, flash track projects need increased capacity or availability of essential personnel and resources to be able to resolve matters immediately. This lean tool has a negative effect on flash track projects.

Supporting Evidence -Low Sui Pheng \& Choong Joo Chuan, (2001) states that in JIT philosophy, the inventory is minimum and the raw materials are not stocked up. However Austin et al. (2016) argues that flash tracking needs increased resources and capacity. 
Rationale - Keeping the site organized using color codes for material reduces time in locating site inventories.

Supporting Evidence -The case study of Thyssen Krupp's Steel Processing Facility presented by Austin (2016) and discussing how the implementation of $5 \mathrm{~S}$ technique eliminated challenges in locating material on the massive and busy site.

Daily Huddle Meetings

Rationale - Daily review of detailed plans, last minute modifications and transfer of plans to craft workers result in better understanding of the tasks which leads to improved schedule performance and productivity.

Supporting Evidence - The case study of Thyssen Krupp's Steel Processing Facility presented by Austin (2016) featured Daily Huddle meetings which increased productivity due to improved collaboration.

$\underline{\mathrm{A} 3}$

Rationale - A3 process can be used to solve problems through root-cause analysis. However, its use in a flash track project depends on the time needed to invest on developing A3 vs the potential time saving value which can be achieved.

Supporting Evidence - No evidence found

\section{$\underline{\text { Kanban (Pull Signal) }}$}

Rationale - Kanban system uses the principle of Just-in-time delivery to pull materials on-site to reduce the inventory. Arbulu et al. (2017) argues that JIT increases labor productivity. They claim that in this "pull system" the products can be replenished quicker than by traditional methods which rely on next day deliveries. However, this will expose an additional risk if the supplier does not have enough inventory of the required product when the project needs them.

Supporting Evidence - Khalfan (2008) states that Kanban uses the principle of Just-in-time to reduce inventory. However, no other evidence, in addition to Arbulu et al. (2003), could be found on how Kanban affects fast track projects.

\section{Poka-Yoke (Error-Proofing)}

Rationale - Error proofing practices eliminates potential mistakes and consequently potential interruptions to the workflow and potential delays.

Supporting Evidence - Tommelein (2008) concludes that mistake proofing practices reduces the time it takes to perform a task and also reducing the variation of that task's duration.

\section{Work Structuring}

Rationale - Work structuring results in creation of work packages and facilitates concurrent engineering and construction. It also helps with achieving lower cycle time which all lead to expediting and fast tracking the projects.

Supporting Evidence - Work structuring was implemented in the fast tracking of Empire State Building. Ghosh \& Robson (2015) states that the work structuring applied to this project facilitated predictable workflow.

Work Standardization

Rationale - Standardization of processes and components can lead to reduced variability and construction times.

Supporting Evidence - Studies conducted by Alistair G.F. Gibb \& Frank Isack (2001) state that owners which used standardized processes and components were able to reduce the construction time, such as a 6-week program reduced to 4 weeks and a 16-week program reduced to 14 weeks.

$\underline{\text { Value Stream Mapping }}$ 
Rationale - VSM can be used to reduce waste of non-value adding activities and thereby reduce the time to perform a task.

Supporting Evidence - Naga Vamsi Krishna Jasti \& Aditya Sharma (2014) concludes that implementation of VSM in the auto industry lead to a reduction in takt time as well as total lead time and process time.

\section{Conclusion}

This paper demonstrates the synergy between lean principles and tools with speed-driven or flash track projects by discussing the rationale and theoretical evidence of lean applications in speed-driven projects. With the goal of improving the schedule performance and productivity, seven lean principles and twelve lean tools were analyzed. Out of eleven, ten lean tools - Last Planner System (LPS), Concurrent Engineering, 5S, Daily Huddle Meetings, Continuous Flow, Poka Yoke, Work Structuring, Value Stream Mapping - were found to have a positive synergy with flash track projects. Flash track projects demand improved workflow and increased productivity. Among these lean tools, Last Planner® System can be considered as the most effective tool to increase collaboration, create more reliable work plan and to remove constraints during the look-ahead planning process. LPS also helps with identifying and procuring long lead items. The use of pull scheduling in Last Planner ${ }^{\circledR}$ System would help reduce rework and waste, thereby resulting in a smooth work flow. Only work packages with mature constraints are released for work thus making the work flow reliable. One lean tool - Just-In-Time (JIT) is perceived to have a negative interaction as flash track projects require increased buffer stocks and capacity of resources while JIT calls for zero inventory.

Ideal conditions for good flow include minimizing cycle time and having stable production rates for different trades. Lean principles advocate good flow. Out of the eight lean principles analyzed, it was found that seven of them - reducing variability, cycle time, batch size, use of multi-skilled teams, pull systems, and instituting continuous improvement - have a positive synergy with flash track projects. Understanding these production flows and applying it to flash track projects can have profound impacts on productivity of the workers as well as the project schedule performance.

This research demonstrates rationally the synergy between lean and flash tracking and documents the practical evidence, future research could further validate these interactions. In the end, it is important to understand the value for the client first and justify lean practices only if needed in a flash track project (Aliakbarlou et al. 2017). This research will benefit construction managers, designers as well as executives, who look to employ innovative construction delivery methods, such as lean construction more confidently in their flash track projects.

\section{References}

Alistair G.F. Gibb, \& Frank Isack. (2001). Client drivers for construction projects: Implications for standardization. Engineering, Construction and Architectural Management, 8(1), 46-58.

Arbulu, R., Ballard, G., \& Harper, N. (2017). KANBAN IN CONSTRUCTION.

Austin, R. B. (2016). Successful delivery of flash track projects. Doctoral dissertation. Georgia Tech. Atlanta.

Austin, R., Pishdad-Bozorgi, P., \& de La Garza, J. (2016). Identifying and Prioritizing Best Practices to Achieve Flash Track Projects. Journal Of Construction Engineering And Management, $142(2)$.

Ballard, H. G. (2000). The last planner system of production control. (D. Seymour, Ed.).

Bertelsen, S., Christoffersen, A. K., Jensen, L. B., \& Sander, D. (2001). Studies, standards and strategies in the Danish construction industry implementation of the lean principles. In: 
Getting it Started Keeping it Going. Proceedings of the 3rd Annual Lean Construction Congress. Presented at the Lean Construction Institute, Berkeley, CA.

Bogus, S. M., Molenaar, K. R., \& Diekmann, J. E. (2005). Concurrent engineering approach to reducing design delivery time. Journal of Construction Engineering and Management, 131(11), 1179-1185.

Fazio, P., Moselhi, O., Théberge, P., \& Revay, S. (1988). Design impact of construction fast-track. Construction Management and Economics, 6(3), 195-208.

Ghosh, S., \& Robson, K. F. (2015). Analyzing the Empire State Building Project from the Perspective of Lean Delivery System-A Descriptive Case Study. International Journal of Construction Education and Research, 1-14.

Khalfan, M., Mcdermott, P., Oyegoke, A., Dickinson, M. T., Li, X., \& Neilson, D. (2008). Application of kanban in the UK construction industry by public sector clients.

Koskela, L. (1992). Application of the New Production Philosophy to Construction. Center for Integrated Facility Engineering, Department of Civil Engineering, Stanford University.

Langford, D., \& Murray, M. (2003). Introduction. In M. Murray \& D. Langford (Eds.), Construction Reports 1944-98 (pp. 1-7). Oxford, UK: Blackwell Science Ltd.

Little, J. D. C., \& Graves, S. C. (2008). Little's Law. In D. Chhajed \& T. J. Lowe (Eds.), Building Intuition (Vol. 115, pp. 81-100). Boston, MA: Springer US.

Low Sui Pheng, \& Choong Joo Chuan. (2001). Just-in-time management in precast concrete construction: a survey of the readiness of main contractors in Singapore. Integrated Manufacturing Systems, 12(6), 416-429.

Moazzami, M., Dehghan, R., \& Ruwanpura, J. Y. (2011). Contractual Risks in Fast-Track Projects. Procedia Engineering, 14, 2552-2557.

Naga Vamsi Krishna Jasti, \& Aditya Sharma. (2014). Lean manufacturing implementation using value stream mapping as a tool; A case study from auto components industry. International Journal of Lean Six Sigma, 5(1), 89-116.

Pishdad-Bozorgi, P., de la Garza, J.M., and Austin, R.B. (2016). Readiness Assessment for Flash Tracking. ASCE, Journal of Construction Engineering and Management. Vol. 142, Issue 12.

Sacks, R. (2008). Production System Instability and Subcontracted Labor. Construction Supply Chain Management Handbook. CRC Press/Taylor and Francis.

Sacks, R. (2016). What constitutes good production flow in construction? Construction Management and Economics, 34(9), 641-656.

Sacks, R., \& Goldin, M. (2007). Lean management model for construction of high-rise apartment buildings. Journal Of Construction Engineering And Management-Asce, 133(5), 374-384.

Sacks, R., Koskela, L., Dave, B., \& Owen, R. (2010). Interaction of Lean and Building Information Modeling in Construction. Journal Of Construction Engineering And Management-Asce, 136(9), 968-980.

Salem, O., Solomon, J., Genaidy, A., \& Luegring, M. (2005). Site implementation and assessment of lean construction techniques. Lean Construction Journal, 2(2), 1-21.

Salem, O., Solomon, J., Genaidy, A., \& Minkarah, I. (2006). Lean Construction: From Theory to Implementation. Journal of Management in Engineering, 22(4), 168-175.

Teicholz, P. (2013). Labor-Productivity Declines in the Construction Industry: Causes and Remedies (Another Look). Retrieved from http://www.aecbytes.com/viewpoint/2013/issue_67.html

Tommelein, I. (1998). Pull-driven scheduling for pipe-spool installation: Simulation of lean construction technique. Journal Of Construction Engineering And Management-Asce, 124(4), 279-288.

Tommelein, I. D. (2008). 'Poka Yoke' or Quality by Mistake Proofing Design and Construction Systems. In P. Tzortzopoulos \& M. Kagioglou (Eds.), 16th Annual Conference of the International Group for Lean Construction (pp. 195-205). Presented at the 16th Annual Conference of the International Group for Lean Construction, Manchester, UK. 